\title{
JUDGMENT WITH CONSENT: ANALYSIS OF SULH INNOVATION
}

\author{
Nor'Adha Abdul Hamid 1,* \\ Faculty of Syariah and Law, Kolej Universiti Islam Antarabangsa Selangor (KUIS), Bandar Seri Putra, 43000 \\ Kajang Selangor, Malaysia. \\ For correspondence; Tel. + (60) 193096889, Email: noradha@kuis.edu.my
}

\section{Roslinda Ramli2}

Faculty of Science and Information Technology, Kolej Universiti Islam Antarabangsa Selangor (KUIS), Bandar Seri Putra, 43000 Kajang Selangor, Malaysia.

\section{Siti Noor Ahmad ${ }^{3}$}

Faculty of Science and Information Technology, Kolej Universiti Islam Antarabangsa Selangor (KUIS), Bandar Seri Putra, 43000 Kajang Selangor, Malaysia.

\section{Mohamad Hafifi Hassim ${ }^{4}$}

Faculty of Syariah and Law, Kolej Universiti Islam Antarabangsa Selangor (KUIS), Bandar Seri Putra, 43000 Kajang Selangor, Malaysia.

\section{Norazla Ab Wahab ${ }^{5}$}

Faculty of Syariah and Law, Kolej Universiti Islam Antarabangsa Selangor (KUIS), Bandar Seri Putra, 43000 Kajang Selangor, Malaysia.

\section{Tuan Nurhafiza Raja Abdul Aziz}

Faculty of Syariah and Law, Kolej Universiti Islam Antarabangsa Selangor (KUIS), Bandar Seri Putra, 43000 Kajang Selangor, Malaysia.

Received date: 12-11-2019

Revised date: 04-12-2019

Accepted date: 19-12-2019

Published date: 29-12-2019

To cite this document: Hamid, N. A. A., Ramli, R., Ahmad, S. N., Hassim, M. H., Ab Wahab, N., \& Aziz, T. N. R. A. (2019). Judgement with Consent: Analysis of Sulh Innovation. International Journal of Law, Government and Communication, 4(17), 102-111.

DOI: $10.35631 / \mathrm{ij} \operatorname{lgc} .4170010$

\begin{abstract}
Disputes are a phase in human life. The dispute is a clash or disagreement of opinion, value, interest or emotion. Civilized communities require guidelines in dealing with any dispute to ensure that life carries on within its range of harmony. Conflicts and disputes are sometimes complex issues that require a settlement mechanism that reflects the taxonomy of the dispute itself, thereby justifying the establishment of a set of legislation and procedures that conform to certain forms and types of disputes. When solving a dispute, Islam promotes a method based on the principle of 'al-Sulh' which simply means peace. Islam truly encourages the practice of such as it highlights efforts of peace-making through acceptance and with the consent of both parties in dispute. Prophet Muhammad very much encouraged his followers to seek peace and avoiding from having disputes with one another. This research uses the qualitative method and the partially-structured interview approach, document analysis, literary research and scientific journals. This research will highlight such and its related provisions and is hoped to provide suggestions to disputing parties and authorities so that they can resolve their disputes faster at a cheaper price and proved to satisfy everyone who is involved by having judgment with
\end{abstract}


consent. The increasing number of registered cases in the Syariah Court indicates the necessity of new method in resolving the dispute by the integration of such concept and Online Dispute Resolution $(O D R)$ to resolve the issue faster and benefits to all the parties.

Keywords: Alternative Dispute Resolution, Islamic Dispute Resolution, Sulh

\section{Introduction}

The practice of sulh can be traced from the history of the Prophet Muhammad S.A.W. It can be seen in several important occasion such as during the conclusion of Hudaibiyah's Agreement in which their dispute was resolved peacefully with a mutually accepted agreement (Tan Yeak Hui \& Asghar). Although the content of this agreement seems not in favour of the Muslims, it has prevented a war between the Muslims and Musyrikin from Makkah and at the same time has brought positive implication to the spreading of Islam in Makkah including the conversion of Quraisy leaders such as Khaled Al Waled to Islam. Another good example of sulh can be seen during the relocation of hajr aswad at the kaabah whereby Prophet Muhammad S.A.W becomes a mediator between the tribes (Siti Noraini \& Zulkifli). In Malaysia, the practice of sulh can be divided into three stages which are during pre-colonial period, during the period of British colonialisation and after the independence. During pre-colonial period, Malay customary practice influenced the Islamic law to apply sulh in all disputes. Imam, ketua kampong, kadi and ulama play their important role as a mediator to settle local disputes (Mohamad Hafiz et. al., 2017). In Malaysia, for example, among the Malay community, the method of solving informal conflicts through mediation and conciliation has long been practiced and is part of the Malay tradition and practice of religion. Elder family members or community leaders in a certain district generally lead this method, be it the village head (Ketua Kampung) or Headman (Penghulu). Although English law developed well and became the main law in Malay states during period of British colonialisation, sulh had been allocated in Article 32 of the Malacca Law and in Pahang Code of Law (Nora, Sa'odah \& Umar 2013). The basis of sulh can be found in several verses from the Quran, such as in verse:8:1:

"They ask you, [O Muhammad], about the bounties [of war]. Say, "The [decision concerning] bounties is for Allah and the Messenger." So fear Allah and amend that which is between you and obey Allah and His Messenger, if you should be believers."

After ages of running the traditional or adversarial trial method, around the last decades of the 70 s, law practitioners and the general public began to realize the weakness that arises out of the adversarial concept of justice. Among the key issues that are often raised are the cases of arrears that ultimately increase legal costs; as well as delay and wastage of time, emotional disturbances and dissatisfaction after a judgment is issued. This situation is not only experienced by the western world but also in the Islamic world. Recognizing this fact, they began to seek an alternative to the traditional trial method. Hence, there are several methods such as mediation, conciliation, consultation and even arbitration, which until today have developed into a community-recognized discipline as Alternative Dispute Resolution (ADR). This is the reason why relevant literature in the field of ADR, are mostly written and investigated by western scholars compared to Islamic scholars. This scenario eventually led to countries like New Zealand, Australia, Canada and England to begin applying the rules mentioned earlier. Similar developments have also occurred in Asian countries such as Japan, China, Korea, Philippines and Singapore. 
And in response to technological advances and trade development in cyberspace, the Online Dispute Resolution (ODR) system were introduced as a dispute resolution system suitable for consumer disputes in that virtual space. ODR exhibits various advantages; among which is the promoting of dispute resolution particularly in cross-border contexts, reducing costs and time as contained in the report of the Victoria Department of Justice, Australia (Tyler \& Bretherton, 2003).

This paper will discuss the sulh concept and its related provisions and is hoped to provide suggestions to disputing parties and authorities so that they can resolve their disputes faster at a cheaper price and proved to satisfy everyone who is involved by having judgment with consent. In response to the interview conducted, among innovations such as e-Sharia, 'TooEasy' and Med-Arb are great innovations done in an effort to assist disputing parties and improving the sulh system in the Sharia Court.

\section{Conflict and Disputes: Judgment with Consent Through Sulh Council}

Dato 'Abdul Hamid bin Haji Mohamad (Judge of the Court of Appeal at the time) in the conclusion of his closing address at the Seminar on Alternative Dispute Resolution Methods in Islam (IKIM) 2001 explicated on the thought that it was undeniable that the best resolution is that which is achieved before going to court or a settlement outside of court. He concluded that the best judgment is judgment with consent. The arbitration system or sulh is an alternative system that can only function if both parties to the dispute agree upon the method and to comply with the results. This cannot be forced, just as the right of the parties to bring any matter to court cannot be eliminated. If forced it will delay the resolution of a dispute. Sulh is part of the process found in the Sharia Court. When parties begin to file their dispute or case, their cases will not be immediately brought before the Assistant Registrar to undergo the hearing process. Any relevant case will be first referred and brought before a Sulh Officer to undergo a sulh session. According to the Practiced Directives of the Sharia Judiciary Department of Malaysia No.1 Year 2010, any of the listed cases have to be referred to the Sulh Council first, the following is the list of the listed case types:

\begin{tabular}{l|l} 
Case Code & Case Title \\
\hline 009 & Engagement Loss Claims \\
016 & Mutaah Claims \\
017 & Joint Property Claims \\
018 & Wife's Alimony Claims \\
019 & Incapable Party Alimony Claims \\
020 & Alimony Collateral Claims \\
021 & Iddah Alimony Claims \\
022 & Claim to change Alimony Orders \\
023 & Alimony Arrear Claims \\
024 & Child Support Claims \\
025 & Claims to change Order on Child Custody/Support \\
026 & Claims to change Child Custody/Support agreement \\
028 & Hadhanah (Child Custody) Claims \\
049 & Marriage Loss Claims \\
059 & Residence Rights Claims
\end{tabular}




\begin{tabular}{l|l}
060 & Order of Reunion Claims \\
062 & Loyal Wife Reunion Claims \\
063 & Dowry Claims
\end{tabular}

Table 1: List of Cases That Should Be First Arbitrated Via Sulh

All of the cases mentioned above are cases that need to be processed by the Sulh Officer in advance. A Sulh notice, rather than the usual mal summons documents, will first be issued in advance to require the defendants to attend the Sulh Council. What is noteworthy is that all the cases listed above are cases of various claims or disputes. Whereas cases involving divorce, fasakh, divorce pronouncement, notation and others will go through the usual Sharia mal procedure and be heard before the Assistant Registrar. Based on the interviews conducted, among all the cases mentioned above, not all such cases can be appropriately resolved through Online Dispute Resolution (ODR) and Community Mediation. This conclusion was reached through the feedback from interviewed informants, which seriously discussed the types of cases appropriate to be resolved through ODR and ADR. Overall the informants interviewed agreed on the implementation of ADR and ODR on the first five types of cases. After a lengthy deliberation the researcher finally settled on case type 024, Child Support Claims, as a reference case for the development of the prototype.

After the parties undergo the proceedings at the Sulh Council and have reached a consensus between the parties to the dispute, then the parties may sign an agreement containing the details that have been agreed in the Sulh Council meeting of which the witness shall be the Sulh Officer. Practiced Directive No.4 of 2011 clarifies that any agreement made in the Sulh Council which is in accordance with Sharia law, shall be brought before the Judge to be revised, and if the Judge agrees, the consent of both parties to the agreement shall be recorded as a court order and shall be enforced. Any such order of consent shall not be appealed or withdrawn by any party. Morever, there are also parties who have prepared their settlement agreement before attending the Sulh Council. This is because it is likely that the parties have discussed and reached a consensus before their case is filed. If such a situation occurs, Practiced Directive No.2 of 2012 states that if there has been a settlement agreement made by the parties or the Sharia Lawyers of the parties in dispute in advance, those cases need not be taken to the Sulh Council at the registration stage. However, Ruzita (2018) explains, these cases need to be reviewed and verified by the Sulh Officer. This is due to the fact that the Sulh Officer is responsible for checking the settlement agreement first made by the parties to ensure it is the best deal and that it does not breach any of the Sharia law. Once settled and certified by the Sulh Officer, only then the agreement will be taken before the Judge to be endorsed as a court order.

Zamni Azura (2018) stated that there arise situations in which either one disputing party could not attend during the process of ratifying the consent agreement before the judge. Practiced Directive No.5 Year 2015 states that, if any party is unable to appear before the judge during the process of verifying the settlement agreement, the non-attendant party shall make such confirmation before any Sharia Court Judge. This provides relief to those who may not be able to present themselves before the Judge concurrently along with the other party.

\section{Sulh and Related Provisions}

At the end of 2002, Aida Melly Tan Mutallib shocked the Sharia judiciary system in Malaysia when she described the release of her divorce letter by the Selangor Islamic Religious Department after six years of waiting "a symbol of her misery" (Raihanah 2004). The initial impression of the statement portrays the dissatisfaction towards the court's delay in resolving 
the case until it was prolonged for a very long period. However, despite this negative reproach, there are some questions that are not clearly and thoughtfully expounded so as to cause endless polemics. Subsequently, the State Legislative Bodies had enacted the provisions relating to the enforcement of sulh so that resolution was not merely based on Islamic law alone but given a source of power that is more robust and undisputable. In general, the provision of sulh, provided in section 99 of the Sharia Courts (Federal Territories) Rules of Procedure Act 1998 which provides for:

The parties to any proceedings may at any stage of the proceedings, hold a sulh to settle their dispute in accordance with any prescribed methods or, if there is no such method in accordance with Sharia law.

The provision of section 99 of the Act constitutes power to the implementation of sulh. It empowers parties to choose to resolve their disputes through the sulh method. This gives them an opportunity, if they are of the view that the trial process is no longer providing justice and can undermine the reputation of the parties involved.

To further smoothen the process of sulh in the Sharia Court, the Sharia Court Methods Committee has been empowered through section 247 (c) of the Sharia Court Mal Proceedings (Federal Territories) Act 1998 to enact a set of jurisdictions relating to sulh. Hence, the Procedures of Mal (Sulh) of the Federal Territories of 2004 was enacted, which contains provisions relating to the implementation of sulh procedures, such as the date of sulh resolution, the absence of the parties to the Sulh Council, the sulh implementation procedure and also the judgment made by mutual consent in the Sulh Council. The purposes of these Procedures are to further clarify any ambiguity contained in section 99 of the Sharia Courts (Federal Territories) Mal Proceedings Act 1998 that only constituted general provisions concerning sulh. Additionally, to further refine the workflow and role played by Sulh Officers, the Malaysian Sharia Justice Department (JKSM) has introduced the JKSM Sulh Work Manual, which has been applied throughout the Sharia Courts in Malaysia. The purpose of the introduction of the Sulh Work Manual is to explain the following points in detail:

I. The process for initiating the Sulh Council;

II. The case presentation by the disputing parties;

III. Mutual discussions;

IV. Single party or caucus meetings;

V. Collective negotiation;

VI. Judgment based on mutual consent;

VII. Confidentiality.

Each Sulh Officer is bound by the Sulh Working Manual in carrying out the sulh process to the disputing parties. Moreover, in implementing this sulh process, sulh officers are also bound by the Sulh Officer Ethics Code as set by the Sharia Judiciary Department of Malaysia (JKSM). The purpose of enforcing the Sulh Officer Ethics Code is to safeguard the responsibility of the Sulh Officer who becomes the person responsible in assisting the parties in dispute. As such, their credibility and responsibility should be carried out in accordance with ethical and legal requirements. In line with the changing of time and circumstances, the process of enforcing sulh in the Sharia Court also requires improvement in the provisions of its laws, the Sulh method and the Sulh Working Manual. As such, the Malaysian Sharia Judiciary Department has taken the initiative by issuing related circulars known as the JKSM Sharia Court Practiced Directives. 
These instructions are administrative circulars that must be complied with by the court, the Sulh Officer and the public. The following are some JKSM Practiced Directives:

\begin{tabular}{|c|c|c|c|}
\hline NO & $\begin{array}{l}\text { PRACTICED } \\
\text { CODE }\end{array}$ & DIRECTIVE & TITLE \\
\hline 01 & No.1 - 2010 & & $\begin{array}{l}\text { Determination of cases that needs to be } \\
\text { referred to the sulh council at case } \\
\text { registration level }\end{array}$ \\
\hline 02 & No. 4 - 2011 & & Impact of Sulh Resolution Agreement \\
\hline $\mathbf{0 3}$ & No.2 - 2012 & & $\begin{array}{l}\text { Settlement / consent agreement made by } \\
\text { Sharia lawyer or parties in dispute }\end{array}$ \\
\hline 04 & No.9 - 2015 & & $\begin{array}{l}\text { Attendance of one of the parties in dispute } \\
\text { before the judge when the order of approval } \\
\text { of agreement is done }\end{array}$ \\
\hline
\end{tabular}

Table 2: List of JKSM Practiced Directives

\section{Revisiting the Sulh Work Process}

Litigation in court is not easy. It involves complicated and complex processes. In this process, the parties involved in the dispute are forced to be defensive and offensive to obtain or retain their respective rights. In this situation, though the court functions as an institution that makes decisions on disputed cases, it is not necessarily achieved through proceedings before a judge. In other words, attending court proceedings is one of the many mechanisms available to resolve disputes. In addition, a settlement or resolution can also be achieved based on mutual agreement or through sulh without the process of litigation. Since 1996, the top management has given serious commitment to the implementation of Sulh Services. This is evidenced by the Sulh Coordination Workshop at the Sharia Court held on the $21^{\text {st }}-23^{\text {rd }}$ August 1996 in collaboration with the JPM Islamic Affairs Division and Perlis State Government in which 2 papers were tabled: Concept of Sulh According to Islamic Law by Prof. Madya Dr. Abdullah bin Abu Bakar and the Implementation of Sulh under the Administration of Sharia Court by Tan Sri Dato' Sheikh Ghazali bin Haji Abdul Rahman;

Aida Melly Tan Mutalib, one of the Sharia Court proceeding sufferees has also expressed open dissatisfaction through the local media on the delay of her case resolution. Such negative promotions have affected the image of the Sharia Court as a whole. This was added upon by the exhortation of DYMM Sultan Sharafuddin Idris Shah as the head of the Selangor Islamic Religion in 2003 over the delay of settlement of the Sharia Court cases, which led to his decree so that a detailed study be carried out regarding the matter (Norita, 2016). JKSM, through its Research Branch has provided sufficient allocation to carry out a research titled "Study on the Period of Solution for Settlement of Marriage Dissolution Cases in All Malaysian Courts (19982002)", which had been conducted for nearly two years. This study did not only involve relatively high cost of travel and accommodation but also the cost of appointing external consultants who carried out professional data analysis.

With the aim of improving the efficiency and effectiveness of the Sharia Court service delivery system as well as benefits to its users, JKSM had established a new service to their users, Sulh Services. The implementation of the Sulh Council was led by the state of Selangor since 2001, followed by Wilayah Persekutuan Sharia Court in 2005 and extending its application to other 
state Sharia Courts. The process of sulh indeed is very convenient to the parties involved. If we look at the litigation process, it takes a long time for a case to be decided by a judge in case trial. There is no guarantee that cases can be resolved in a standard period. It depends on the process of case management, registration, designation and finally the trial itself. Although the court has set a certain period of time for a case proceeding, for example the date of a case hearing shall be fixed within 14 days after the case registration. Problems still arise if the defendants do not present themselves within the prescribed period, thus causing the process to be delayed. Therefore, with the process of sulh in the Sharia Court, the problems associated with time and delay can be resolved. The disputing parties only attend the sulh process once or twice and if successful, the order may be issued within a few hours, subject to the consent of the Judge (Ruzita \& Ridhuan, 2018).

The strength of the sulh process can be identified through the effective cost saving by the disputing parties. The disputing parties are not required to appoint a Sharia lawyer to represent them in court. It is common knowledge that the cost of appointing a Sharia lawyer is not cheap. The more complicated the case is, the higher the charges imposed by the Sharia lawyers. Additionally, if a said Sharia lawyer has long been practicing and has a brilliant reputation, their fee also increases. However, the sulh process does not require a lawyer's presence. Hence, it is cost saving on the disputing parties. However, the parties to the dispute are required to settle the case registration fee during the registration process at the court counter, this is imposed once and is a standard charge.

The objective of the litigation process in court is to resolve a dispute through trial and judgment by the hearing Judge based on the evidence submitted to the court by the disputing parties. In contrast to the sulh process, the parties themselves will discuss and find the best solution to their problems. They will make decisions based on their mutual sound judgment and benefit. However, in contrast to the litigation process, it is not necessary that the parties are satisfied with the judge's decision, if they are dissatisfied, the aggrieved party will file a notice of appeal within 14 days. This will result in cases that while initially could be resolved, become postpone pending the appeal process.

\section{Sulh Innovation}

Along with the current challenging developments, sulh process requires further innovation based on existing mechanisms. The sulh system is an alternative system that can only work if both parties to a dispute agree to comply with the results. It cannot be forced. Their right to the Court also cannot be eliminated. If forced it may further delay the resolution of a dispute. For example, it can be noted that a Reconciliation Committee established under the Law Reform (Marriage and Divorce) Act 1976 (LRA 1976) is less effective. This compulsory reconciliation for couples who wish to divorce under section 53 of the LRA, 1976 has been severely criticised. Some criticisms attacked the very basis of this concept that reconciliation does not work in the Malaysian society because most couples would have exhausted all avenues of reconciliation before they even petition for the divorce (Mimi 1999). The couple when they are referred to the reconciliatory bodies, like, marriage tribunal, already made up their mind to dissolve their marriage. Thus, any effort to repair the relationship between them does not work anymore (Norlia \& Nora 2017).

In the early stages of sulh implementation there were no obstacles and constraints. This is because the problems inherent to the process could not be detected since its inception. However, as time progresses, we can see that the process of sulh needs to grow in line with current 
developments, but while still maintaining the process of settlement. Zamni Azura (2018) pointed out that there was a critical problem in the implementation of sulh; that the disputing parties did not want to talk at all. Embedded in their minds is the thought that a Judge should hear their case in Trial. This view will inhibit the original objectives of sulh that is to expedite the settlement of cases in court. In addition, Fadhlina \& Aqmar (2018) looked at the initial point of the sulh process, it used the manual method of data storage through a filing system. It did not seem practical because the Sulh Officer needs to regularly update the files pertaining to disputing parties. It was already time-consuming without adding the growing number of parties in dispute every single day. Worse still were the complaints from parties that their documents kept under the care of the Court Officers had disappeared.

To address the existing issues, the Malaysian Sharia Judiciary Department (JKSM) had launched an e-shariah system. This system is a centralized system that is directly linked to JKSM in Putrajaya. E-Sharia is the seventh Electronic Government project under the Multimedia Super Corridor (MSC) Application. It is an integrated case management system that melds all processes involved in the handling of cases in the Sharia Court. An electronic network linking Sharia Courts with the Malaysian Sharia Judiciary Department (JKSM) and related agencies was also created for coordination and information sharing.

E-Sharia brought changes and reforms to operations in the Sharia Court. It also streamlined case management as well as standardized the process of registration of Sharia lawyers. Daily office automation was enhanced through the use of the Office Automation System while the JKSM Library Management System simplified the process of ordering books and library materials for the reference of Judges and Registrars of Sharia Courts. Through the E-Sharia Portal people can check on court procedures, the latest rules and make inquiries about the status of a case. Faraid computations were also made electronically. With the implementation of the e-Sharia system, Sulh Officers no longer need to store details manually. All registrations will be stored in this system. In fact, if there is a problem, the Sulh Officer can merely reprint the desired information. Apart from that, (Ruzita \& Ridhuan, 2018) highlighted that the Sulh Officers involved need only to include the form of agreement that has been reached by both parties into the system and it generates the necessary order to be endorsed before a judge to make it a court order.

Looking at the number of disputing parties who have registered their cases in court increasing each year along with the various problems that arose with it, the Melaka Sharia Court implemented their own innovative initiative known as 'Too-Easy'. The 'Too-Easy' innovation is very convenient in a sense that when a case is brought before the Sulh Officers with a failed status or if either party in the dispute does not want to pursue their case, the court will hand over the summons and statements of claim to the defendant on the same day. After which, the court will release an affidavit to be acknowledged by the defendant immediately. Upon which the court will allow 14 days for the defendant to enter their defense and counterclaim and recall the case. This innovation has saved the court a huge amount of time, in contrast to the original procedure, where when a case has a failed status, the parties will return home and the summons and claim statement will be released the next day. This will result in the defendant dismissing or refusing to accept the summons (Ruzita \& Ridhuan, 2018).

A very interesting and seemingly effective innovation was also implemented by the Selangor Sharia Judiciary Department, which is the introduction of a procedure called Med-Arb. This procedure is very helpful to the parties because, if the parties to the dispute do not reach a 
mutual understanding, the Sulh Officer will ask the parties to fill out a form to appoint the Sulh Officer as an arbitrator or judge. With the power of arbitration, this Sulh Officer functions as an arbitrator and initiates the arbitration process. The Sulh Officer may prescribe any decision that may be reasonable in the interest of both parties. Then, the decision will be recorded and brought before a judge to be recorded as a court order (Yuszairi, 2018), which is considered as judgment with consent. As sulh is part of the Sharia Court's work process, it is the responsibility of the court to ensure that all these procedures and work movements go smoothly. Of course, every procedure and work manual needs to be continuously improved and requires innovation as the development of humans and their behavior is also influenced by the change of time and circumstance. Innovations such as e-Sharia, 'Too-Easy' and Med-Arb are great innovations done in an effort to assist disputing parties and improving the sulh system in the Sharia Court.

\section{Conclusion}

In conclusion, the integration and innovation between the sulh process and mediation is seen to be very good in helping disputing parties to quickly and effectively resolve their disputes in the presence of a Sulh Officer. The effectiveness of the sulh process and mediation can be seen through the key indicators of saving times, saving costs and the satisfaction of parties for the settlement of their dispute. In line with current developments of ICT, the sulh-based Online Dispute Resolution process is seen to be more significantly effective in helping disputing parties to accelerate the resolution process, and importantly to arriving the judgment with consent for all disputes brought before the court of law. Following the doctrine of 'justice delayed is justice denied' by the courts, the judgment with consent via sulh innovation is indeed the new face of ODR in Sharia court system.

\section{References}

Hak N. A., Ahmad S., Oseni U. A., (2013), Alternative Dispute Resolution (ADR) in Islam, Kuala Lumpur: IIUM Press, Selangor.

Hui T. Y. \& Ali Mohamed A. A., Mediation/conciliation in the Malaysian Courts: With Em phasis on Settlement of Labour Disputes, Malaysia: Hui \& Mohamed, pg4.

Melissa Conley Tyler, Di Bretherton (2003) Research into Online Alternative Dispute Resolution: Exploration Report Prepared for The Department of Justice, Victoria. The International Conflict Resolution Centre, Department of Psychology, The University of Melbourne.

Mimi Kamariah Majid. (1999) Family Law in Malaysia. Kuala Lumpur: Malayan Law Journal, p. 188; See also Round Table Discussion. (2009, May). Keberkesanan Badan Pendamai Di Bawah Seksyen 106, Akta Membaharui Undang-undang (Perkahwinan dan Perceraian) 1976 (Akta 164).

Mohammad Hafiz Bin Mohd Zaki, Mazbah Termizi, Muhammad Ridhwan Saleh, Nina Syazmeen binti Mohd Din \& Siti Farhana binti Abu Hasan (2017). Mediation v. Sulh: A Comparative Study. International Conference on Dispute Resolution 2017: Modern Trends in Effective Dispute Resolution, 9 - 10 August 2017, page 219.

Mohd Ali S. N., Hassan Z., Perlaksanaan Sulh Dan Keberkesanannya Di Mahkamah Syariah Selangor, Malaysia.

Norita Kamaruddin (2016) Konsep Sulh Menurut Perspektif Islam Dan Aplikasinya Dalam Mahkamah Syariah Di Malaysia. Kertas kerja dibentangkan di International Conference on Aqidah, Dakwah and Syariah 2016 (Irsyad 2016).

Norliah Ibrahim, Nora Abdul Hak (2017). Resolution of Matrimonial Property Dispute in the Civil Court of Malaysia: Mediation As A Way Forward. International Conference on 
Dispute Resolution 2017: Modern Trends in Effective Dispute Resolution, 9 - 10 August 2017, page 65.

\section{Statutes}

Law Reform (Marriage and Divorce) Act 1976

Practiced Directives of the Sharia Judiciary Department of Malaysia No.1 Year 2010 (Arahan Amalan Jabatan Kehakiman Syariah Malaysia No.1 Tahun 2010).

Practiced Directive No.5 Year 2015 (Arahan Amalan Jabatan Kehakiman Syariah Malaysia No.9 Tahun 2015).

Practiced Directive No.2 of 2012 (Arahan Amalan Jabatan Kehakiman Syariah Malaysia No.2 Tahun 2012).

Practiced Directive No.4 of 2011 (Arahan Amalan Jabatan Kehakiman Syariah Malaysia No. 4 Tahun 2011).

Procedures of Mal (Sulh) of the Federal Territories of 2004 (Kaedah-Kaedah Tatacara Mal (Sulh) Wilayah-Wilayah Persekutuan 2004).

Sharia Court Mal Proceedings (Federal Territories) Act 1998

\section{Interview Sessions}

Interview with Nurul Fadhlina Binti Che Daud (Sulh Officer, Jabatan Kehakiman Syariah Negeri Sembilan), $17^{\text {th }}$ April 2018.

Interview with Muhd Ridzuan Bin Zainuddin \& Ruzita Ali (Sulh and Research Officer, Jabatan Kehakiman Syariah Negeri Melaka), $23^{\text {rd }}$ April 2018.

Interview with Zamni Azura Mohd Sarin (Sulh Officer, Jabatan Kehakiman Syariah Wilayah Persekutuan (Putrajaya), $24^{\text {th }}$ April 2018.

Interview with Tuan Muhammad Yuszairi Bin Mohd Zamzam (Judge of Shah Alam Shariah Court), $30^{\text {th }}$ April 2018. 